\title{
Chang Chien's Ideas and Activities on Constitutional Monarchy
}

\author{
Sun, Shun-chih \\ Department of Translation and Interpretation Studies \\ Chang-Jung Christian University \\ No.396, Sec.1, Chang Jung Road, Kuei-jen, Tainan 711, Taiwan \\ E-mail: scsun16@hotmail.com
}

\begin{abstract}
Chang Chien was born on July $1^{\text {st }}$ in 1853 in Haimen Kiangsu and died on August $24^{\text {th }}$ in 1926 in Nant'ung Kiangsu. Chang Chien's ideas and activities on constitutional monarchy are significant and thus this article is to examine them.

Constitutional monarchy, according to Chang Chien, was a separation of the three-power political system under an emperor. In order to accomplish constitutional monarchy, local self-government should be strengthened and therefore without local self-government, constitutional monarchy was impossible to be really achieved.

Special characteristics of Chang Chien's constitutional thought can be categorized as: (1) constitutional monarchy is related to industry, education and local self-government; (2) He prefers to middle-way, reform, and golden means.

Chang Chien had played a very important role in the constitutional movement. In the gestation period of 1904-1906, he acted behind the scene to push the Ch'ing government to adopt constitutionalism; In the developing stage of 1907-1911, he advocated the petition-for-a-parliament movement and as a result the Ch'ing government shortened the preparation period toward constitutional government by three years or so.
\end{abstract}

Keywords: Constitutional Monarchy, Local Self-government, Industry, Education

\section{Introduction}

The purpose of this article is to examine Chang Chien's thoughts on constitutional monarchy with special reference to his ideas and concerns of Chinese constitutional movement especially during the period 1909 to 1911 . He played a very important role in the petition for a constitutional government in 1910 and finally forced the Ch'ing government to shorten the period of preparation toward a constitutional government by three years or so.

Constitutional monarchy, according to Chang Chien, was a separation of the three-power political system under an emperor. But he did not discuss who were entitled to vote for, and to be elected as, members of parliament. In order to accomplish constitutional monarchy, self-government should be strengthened and therefore without self-government, constitutional monarchy was impossible to be really achieved. Self-government, according to Chang Chien, meant that everyone should devote himself to the development of industry, education and other local affairs under the leadership of the gentry, the representatives of the people, and hence local councils were essential to self-government. Therefore, Chang Chien's thought on self-government was realistic (Wang Tung-ch'in, 2007:266)

Chang Chien saw self-government as the basis of a constitutional monarchy. He expressed this point of view on different occasions, in 1906:

Self-government is the essential basis of constitutional monarchy ( Chang, Hsiao-jo, 1983, Cheng Wen Lu (On Politics), chuan 3,13a).

And in 1910, he praised the Ch'ing government's regulations for self-government:

The emperor has issued "The Regulations for the Local Self-government of Cities, Towns and Villages". These regulations see self-government as the root of constitutional monarchy, and see cities, towns and villages as the primary foundation of self-government ( Chang, Hsiao-jo, 1983, Tzu Chi Lu (On Self-government), chuan 1, 11a).

And on June, 13, 1911, in Peking, Chang Chien told the Regent, Tsai-feng : 
I have been paying particular attention to the affairs of Local self-government since Emperor Kuang Hsu introduced new reform in 1906 on constitutional monarchy ( Chang, Chien, 1986,13/06/1911(the seventeenth day of May, the third year of Huan-t'ung Emperor) ).

Chang Chien always took a moderate, middle-way, gold means, step-by-step, and practical stand in the fulfilment of the affairs of self-government and constitutional monarchy. He took actions rather than empty rhetoric. He believed that the success of the reform movement depended on a functional division and cooperation between the government and the gentry. The task for the government was to enforce a political reform, that is, to establish a constitutional government; the task for the gentry was to foster social reforms, including educational and economic modernization which he referred to as "Local self-government" ( Wong, king-kong, 1957:40).

In 1906, while his colleagues were arguing over the relative speed with which the constitutional movement should be pushed, he was willing to let the ultimate initiatives come from the government. For private individuals, he believed, industry, education, and self-government should be the primary concern. He urged the government to inaugurate a constitutional regime and also advised the gentry to promote educational and economic modernization. He told them:

It is the responsibility of the government to establish a constitutional regime, and we the people should promote the local self-government by engaging ourselves in educational and economic careers. It is better to act than to talk. An advance from poverty and illiteracy to richness and literacy of even a foot or an inch is valuable ( Chang, Hsiao-jo, 1983, Chuan Lu (Special Section), chuan 7, 14b).

Chang Chien was not a man equipped only with armchair strategies. He preferred to action rather than words. This trait help him in various enterprises including cotton mills, and educational institutions including normal schools in his home district, as well as in the promotion of local self-government and constitutional monarchy. He personally devoted himself to the development of industry, education and other affairs of local self-government in order to achieve a constitutional monarchy, and later a republic.

Chang Chien thought that local self-government and constitutional monarchy were related and mutually influenced, and thus he was inclined to have a parliament to define the shape and size of taxation. In his article of "Appeals for a Parliament for the control of taxation and Expenditures for Self-government", Chang Chien explained this in 1910:

Taxation regulations bear upon the success or failure of self-government and the life or death of tax-payers. Is there any country in the world that is known to have laid down taxation laws without their having passed through the parliament? ...Self-government presupposes money, money comes from taxation, taxation must be systemized and proportioned, and taxation system and rate require the work of a parliament. Hence it is almost impossible to deliberate and plan the local self-government affairs for a constitutional monarchy unless a parliament is available ( Chang, Hsiao-jo, 1983, Tzu Chih Lu (On Local Self-government), chuan 1, 13b-14a).

Therefore, special characteristics of Chang Chien's constitutional thought can be categorized as: (1) He prefers to middle-way, reform, and golden means rather than revolution (Wang Tun-ch'in, 2007:29); and (2) Constitutionalism is related to industry, education and self-government.

\section{A Brief Look at Chang Chien's Careers and Thought}

Chang Chien, $t z u$ ( courtesy title ) Chi-chih, hao (alias) Se-an, and Se-Weng, was born the fourth of five sons, on July 1, 1853 in the village of Ch'ang-lo, Hai-men, Kiangsu, and died on August 24, 1926 in Nant'ung, Kiangsu. Chang Chien began his student days in 1856 at the age of only four. His first teacher was his father Chang, P'eng-nien, who taught him to read Book of A Thousand Characters. The following year, 1857, Chang Chien was sent to a village school. The teacher was Ch'iu, Ta-chang, under whom Chang Chien in a period of seven years ( 1857-1863 ), had finished the primers such as Trimetric Classics, and Books of Family Names; the basic poetic readers such as Works of A Thousand Poets, and Poems of A Boy Prodigy; and the Confucian Classics such as The Great Learning, The Doctrine of Golden Means, The Analects of Confucius, Mencius, The Filial Piety Classic, and The Book of Odes. The study of these books served as a basis for examination work, though they were for elementary education only.

In 1864, his father employed Sung, Hsiao-ch'i as family teacher to help Chang Chien and his brothers in the preparation for local examinations. The teacher asked Chang Chien to study again The Great Learning, The Doctrine of Golden Means, The Analects of Confucius, and Mencius, but from better editions. Then he proceeded to teach the boy The Book of History, The Book of Change, The Book of Rites, and T'so's Commentary of the Spring and Autumn Annals. Under his teacher's effective guidance, Chang Chien learned to write examination poems and examination essays which were required in the examinations. Unfortunately, this enthusiastic teacher died in the Summer of 1866, and Chang Chien was sent to follow Sung Lin, the dead teacher's nephew, in a neighbouring village, Hsi T'ing. Under the new teacher, Chang Chien advanced to study two more Confucian Classics, The Rite of Chou and The Book of Ritual ( Chang, Hsiao-jo, 1983, Chuan Lu, chuan 6, 2a-4b). 
Chang Chien's examination life was a long and toilsome history. In the first stage, Chang Chien was lucky enough. He spent only five years, 1864-1868, in preparation, successfully passed through the district, prefectural, and Yuan ( one conducted by provincial literary examiners ) examinations, placing twenty-sixth in the latter, and was classified a Fu-sheng (licentiate) in 1868, at the age of sixteen ( Chang, Hsiao-jo, 1930:25-26).

The second stage was very hard for Chang Chien. He spent seventeen more years, 1869-1885, failed five times in the provincial examinations. In 1870 he tried for Chu-jen degree for the first time, and succeeded in placing sixteenth in the k'o examination but failed to pass the provincial examination. He was to repeat this pattern of succeeding in the k'o examinations and failing in the provincial examinations four times in 1873,1875, 1876, and 1879. The degree of Chiu-jen continued to elude him until 1885, when he competed in the provincial examination and succeeded in placing second highest among who passed.

Chang Chien spent nine more years, 1886-1894, in preparation, failed repeatedly four times in the examinations for Chih-shih degree in Peking in 1886, 1889, 1890, and 1892. In 1894, at the age of 42, Chang Chien, at the insistence of his elder brother, Chang Ch'a, and the encouragement of his aged father, once more took the metropolitan examination. This time, his name was found in the sixtieth position. He improved on this in the re-examination by placing tenth, and when the palace examination was over, he was chosen to be Chuan-yuan, the highest of all. He was duly appointed a Compiler of the First Class in the Hanlin Academy. Unfortunately, only six months after he had won the highest title of Chuan-yuan, he lost his father, who had played the most important role in his examination life. Four years later, in 1898, when he had decided to take no office in the government and when he was busy promoting local development in his home area, Chang Chien did not forget to come back to Peking for his last examination in Hanlin Academy. According to himself, this unnecessary effort was again to fulfil the dream of his deceased father.

Chang Chien's life of 74 years witnessed a series of momentous intellectual changes and incidents: the Self-strengthening Movement in 1860-1894, the Hundred Days of Reform in 1898, the Boxer Incident in 1900, the Constitutional Movement in 1905-1911, the Revolution of 1911, the May Fourth Movement around 1919, and the rise of communists from1921. It was against this backdrop of intellectual changes and incidents that Chang Chien's thought developed. His thought and activities in turn played a part in shaping modern China. Chang Chien played a key role, especially, in the promotion of China's earlier industrialization and education, in the petition for an earlier convening of a parliament in 1909-1910, and during the period of North-South Negotiation in 1911-1912.

Through the traditional training, Chang Chien had accepted the pragmatic and the reciprocal aspects of Confucianism which later functioned as his guiding spirit in promoting industry, education and self-government as the foundation of a constitutional monarchy, and then a republic. Chang Chien believed that the best way is somewhere between the two extremes. As he understood it, there were no basic conflicts between the Chinese tradition and Western civilization. It was possible to find some form of compromise by adhering to the broad principles of Confucianism and adopting Western technology, organization, and even political system of constitutional monarchism and republicanism. Chang Chien thought that "practical use" might be changed but "basic principle" should be permanent and could not be changed. Chang Chien's ideas on industry, education, self-government, constitutional monarchy and republic had changed according to situations, but Chang Chien's belief on Confucian ideas of serving the people had never changed.

With the pragmatic and reciprocal aspects of Confucian ideas serving the people, adjusting to China's concrete situations, Chang Chien developed his thought firstly, saving China by industry from 1866, the time self-strengthening movement in progress; secondly, saving China by industry and education from 1895 to 1900 , the time after Sino-Japanese War; thirdly saving China by industry, education and self-government from 1900 to 1903, the time self-government movement in progress; fourthly saving China by industry, education, self-government under a constitutional monarchy from 1903 to 1911, the time constitutional movement in progress; and lastly, saving China by industry, education, self-government under a republic from one month after 1911 Revolution, the time he changed to a republican, until his death in 1926. Chang Chien indeed had successfully made considerable contributions to China's economic, educational and political modernization. The case of Chang Chien's subtle promotion of China's modernization demonstrated clearly that Confucianism was not necessarily incompatible with modernization (Sun, Shun-chih, 1995:98).

The main lines of Chang Chien's political thought may be briefly summarized as follows: industry is the basis of education; education and industry are the foundation of self-government; and self-government is the basis of constitutional monarchy ( or later, a republic ). The ultimate purpose of his political thought was to make China wealthy and powerful. Please look at Figure 1 at the end of this article.

Chang realized that for the local people public services and economic development were equally urgent, but for those who would initiate local modernization in various fields the industry were most urgent. They had to obtain sufficient funds by operating some economic enterprises before they would have the resources to establish various social services. He also realized that after the initial stage the maintenance and development of self-government institutions would depend on the income of the local people. He recognized that people have to be rich before they are able to be educated. 
Thus the first step for him to take in his self-government program was the establishment of Da Sun Cotton Mill in T'ung-chou in 1896. Later, a number of economic enterprises such as cotton mill, land reclamation, salt manufacture, flour milling, glassmaking, wine-making, machine manufacture, match manufacture, shipping, banking and fisheries were established and modernized one after another in T'ung-chou under the promotion, direction and management of Chang Chien. As Chang Chien admitted in later years, the development of education, social welfare and others in T'ung-chou was really a result of the development of these economic enterprises.

Chang Chien had personally undertaken the responsibilities of rescuing people from poverty and ignorance to richness and knowledge by promoting industry, education, water conservation, and civic and philanthropic enterprises such as the public granary; the benevolent institution for the relief of the destitute; the survey maps; the local prison; the law-enforcement agencies; the police training schools; the foundling home; the homes for the aged; the workshops for the poor; the medical clinic; the home for the disabled; the school for the blind and dumb; the publishing house; the museum; the library; the meteorological station; the theatre; the dramatic school; the parks; and the network of paved motor roads. Finally, Nant'ung had become a new world and a model district of China (Yu Li-tzu, 2007:1-2). The Nant'ung story illustrates how, in early 20th century China, using new commercial means to exhibit modernity and promote political images was taken for granted (Shao, Qin, 2004:286).

\section{Chang Chien's Ideas and Activities on Constitutional Monarchy}

Before 1895, Chang Chien mainly spent his time in preparing civil service examinations, the ladder of success in the imperial China, and hence he expressed no idea of constitutional monarchy at this stage. During the period from 1895 to 1900 , he had the idea of mutual assistance of industry and education, but he still had no idea of constitutional monarchy yet. Chang Chien did not mention self-government until 1901. After his return from Japan in 1903, Chang Chien's ideas on constitutional monarchy was great crystallized by the example of Japanese experience; During the period from 1906 to 1911, he thought that self-government was the basis of constitutional monarchy; During the period 1912 to 1914, he hoped that self-government could be implemented under the republic; and thereafter until his death in 1926, he devoted himself to the cause of self-government though it was neglected by central government.

\subsection{The Gestation Stage of 1904-1906:}

\section{leading to Ch'ing government's 9-year Preparation for Constitution Monarchy}

Chang Chien identified constitutional monarchy with the establishment of a parliament and a responsible cabinet, and the making of a constitution to accomplish a separation of the three-power political system under an emperor. In his preface to a Chinese translation of The History of Japanese Parliament authored by Kosogava Hirosei in 1906 Chang Chien said:

Constitutional monarchy presupposed a written document by which a separation of the three-power (legislative, executive and judicial power) political system can be established. Just as the Westerners have said, political rights can not be granted unless an adequate political system is available ( Chang, Hsiao-jo, 1983, Wen Lu (Essays), chuan 6, 5a).

However, who should be members of the Parliament? Who should have the right to vote for the members of the parliamentarians? Chang Chien did not discuss these matters in detail. As far as we know, he preferred to let the intellectuals and the rich to be the memberships of the Parliament and this was very similar to the early stage of democratic development in Britain.

The need for a written constitution in China was first emphasized by K'ang Yu-wei in his 1898 memorials. The constitution that $\mathrm{K}$ 'ang had in mind was patterned after the Japanese constitution of that time, which framed a constitutional monarchy. He proposed to establish a Chih-tu-chu (Laws Drafting Bureau) to draft the constitution, but during the short period of his Hundred Days' Reform the drafting of a constitution had not been ordered. In the years after the failure of 1898 reforms there had been no demand for a constitutional government either from the officials or the gentry ( Wong king-kong, 1957:41). It was Chang Chien in 1901 in his Pien-fa P'ng-I (Reasoned Discussion on Reforms) in which he suggested a National Assembly made up of members appointed by four or five ministers, themselves to be members of the assembly. Its function would be the deliberation of the proposed reform programs or any feasible reform measures, and the planning of the various stages of reforms to be carried out ( Chang, Hsiao-jo, 1983, Cheng Wen Lu (On Politics), chuan 2,1b-2a). At that time Chang Chien himself did not recognize the need to change the basic political structure of the country. The reforms embodied in the Reasoned Discussion on Reforms would only graft some new branches of specific improvements onto the old tree of the existing government structure ( Samuel C. Chu,1965:60). However, Chang Chien personally had a very favourable impression of the Japanese Genroin or Senate of the early Meiji era, which was created in 1875 to enact laws for the emperor and dissolved in 1890 when the Imperial Constitution was promulgated and the House of Peers was established. The Genroin in fact did not have any representative or elective character ( Joseph M. Goedertier,1968:58). At this time, Chang Chien gave the Manchu Court a hint that it would be wise to set up a National Assembly patterned after the Genroin of the Meiji period. He stressed that the Genroin had successfully played a dual role, that is, enacting new laws and amending existing laws 
for the emperor on one hand, and serving as a go-between to facilitate communications between the above and the below on the other hand ( Chang, Hsiao-jo, 1983, Cheng Wen Lu, chuan 2, 1b-2a).

Of course, the proposed "National Assembly" would have only the most limited power, and its members were suggested to be appointed by "four or five ministers", and hence it could not be compared to the Parliament of today. However, it might be regarded as an initial or transitional institution toward the adoption of constitutional monarchy.

The idea that a constitution was a desirable thing in itself first came to him on his trip to Japan. Early in 1903, Chang Chien accepted an invitation to attend the fifth Japanese industrial exhibition which would be held in Osaka in the summer of the same year. He boarded the ship in the morning on May 23, and arrived in Japan in the evening on May 24. During his sixty-four-day sojourn from May 24 to July 27 in Japan, he visited thirty-five educational institutions and thirty agricultural, commercial, and industrial enterprises. Japanese accomplishments made a deep and favourable impression on him. He reasoned that, if Japan, endowed with less advantage than China, could be so advanced in industry and education, she had to possess something which China did not. The obvious thing was her constitution (Chang, Hsiao-jo, 1983, Chuan Lu, chuan 4, 1a-33a). On his return, he took every opportunity to discuss a possible constitution with his friends and to induce their cooperation. In the April of 1904, he held discussions on the topic of constitutionalism with K'uai Kung-tien of Hofei, Anhui ( Chang, Hsiao-jo, 1983, Chuan Lu, chuan 7, 11b). In the May of 1904 he was asked by governors-generals Chang Chih-tung and Wei K'uang-t'ao to draft a memorial requesting the adoption of a constitution by the imperial court. He fulfilled the task after consulting a number of his friends and revising the draft seven times. Nevertheless, it seemed that Chang Chien was not satisfied with this draft memorial, in which he privately commented that words were too gentle and ingratiating and the tone was lacking in courage. In June 1904, Chang Chih-tung further gave instruction to Chang Chien that Yuan Shih-k'ai, then governor-general of Chili and the imperial superintendent of trade for northern China (Pei-yang Ta-ch'en), should be consulted in regard to constitutionalism; and T'ang Shou-ch'en, Chang Chien's friend also persuade Chang Chien in so doing. Under this circumstance, although Chang Chien had not made contacts with Yuan for twenty years since his return from Korea in 1883, he took the initiative to resume the old friendship, purely for the cause of constitutional government, he wrote Yuan a letter asking for support. Yuan replied that it still was not the proper time yet to introduce constitutionalism at this stage ( Chang, Hsiao-jo, 1983, Chuan Lu, chuan 7, 12a). And therefore the submission of this memorial finally suspended due to Yuan Shih-k'ai's cautions attitude ( Daniel H. Bays, 1978: 250). It was Chang Chien's way of thinking that in addition to the efforts and appeal of the gentry, the commitment of influential officials and their willingness to submit memorials were the key to accelerated adoption of a constitutional monarchy by the imperial court. Chang Chien himself, a leader of the gentry and merchants and a noted scholar, who enjoyed good relations with many distinguished people in government circles at this time was unquestionably the best qualified person for the role in the formation of an alliance between officials and gentry ( Liao, Sheng-hsiung, 1979:270).

Chang Chien's effort for constitutionalism was not only directed towards powerful officials, but also towards the Manchu Court. In July 1904, he completed the printing of The Constitution of Japan. His friend Chao-Feng-ch'ang sent twelve copies of the book to the capital, some of which eventually fell into the hands of the Empress Dowager herself. This book seemingly attracted the interest of the Empress Dowager, Tz'u-hsi. Afterwards, on a summons occasion, the Empress Dowager made such a remark: "That Japan has a constitution is very good to the country". Officials at the scene were stunned and unable to respond. Immediately after this episode, Grand Secretary Ch'u Hung-chi dispatched his younger brother to Shanghai to collect work on constitutionalism. Chao Feng-ch'ang was asked to lend a hand to this task. Interestingly, both Ch'u brothers were ignorant of the fact that Chao was one of publishers who circulated The Constitution of Japan. Learning this, Chang Chien deeply sighed. He doubted the value of ruling officials who were blind to current developments ( Chang, Hsiao-jo, 1983, Chuan Lu, chuan 7, 12a).

In September of 1904, he printed another book JI-pen Hsien-fa I-chieh I-hui Shih (Japanese Constitution and Diet: An Interpretive History). He sent copies of it to another influential and progressive-oriented Manchu, Tieh-liang in Nanking. Of course, Chang Chien did not miss this good opportunity to have discussions on constitutionalism with him ( Chang, Hsiao-jo, 1983, Chuan Lu, chuan 7, 12b). Pleasant discussions on constitutionalism drew these two reform minded men closer. Thereafter, primarily for the governmental affairs, they kept in constant touch with each other.

As a matter of fact, since the failure of the Boxer Movement, the Empress Dowager and her conservative supporters had awakened to the fact that mere anti-foreignism could by no means save the empire. After 1901, they had no choice but to effectuate most of the reform programs originated by K'ang Yu-wei and his associates during the under Days of reform in 1898. On the list of needed reforms were establishing new educational systems, sending students abroad, adopting Western military methods, developing agriculture and industry, instituting better laws and taxes, abolishing sinecures and corruption, and so on. The dynasty's reform efforts were not merely opportunist responses to the pressure of the revolutionary movements but concrete attempts to revive the empire. For modern purpose, some reforms of the administrative structure at Peking were also inaugurated in the first years of 1900s. For example, the Tsung-li Yamen in 1901 became a full-scale Ministry of Foreign Affairs (Wai-wu Pu); A ministry of Commence (Shang-wu Pu) was 
established at the capital in 1903; and a law-compilation bureau began work in 1904 ( John K. Fairbank, Edwin O. Reischauer, and Albert M. Crag,1965:614-615;623). Nevertheless, as a whole, those reforms of the early 1900 were still conservative, and the political structure of the Ch'ing dynasty remained unchanged.

Government personnel in the very beginning of this century were entirely in the hands of Jung-lu and Prince Ch'ing (I-kuan, 1836-1916). Among the important governors-general were Li-Hung-chang, Yuan Shih-k'ai, Chang Chih-tung, and Liu K'un-i. Shortly after the signing of the Boxer Protocol, Li Hung-chang died in 1901. and Yuan Shih-k'ai succeeded Li as Chili governor-general. After Liu K'un-I's death in October 1902, Yuan Shih-k'ai and Chang Chih-tung became the leading governor-general. In April 1903, Jung-lu also died, leaving Price Ch'ing as the pillar among the nobles. In former times, Yuan had flattered Jung-lu in order to secure special favour from the Empress Dowager. After Jung-lu's death, Prince Ch'ing was similarly used by Yuan. Holding the position of governor-general of Chili from 1901 to 1907, Yuan worked closely with Prince Ch'ing, and consequently brought himself very close to the imperial power centre. Prince Ch'ing and Yuan Shih-k'ai accordingly emerged as the two most important figures of the empire, with power considerably greater than that of Chang-Chih-tung ( Teng, Ssu-yu and Jeremy Ingalls, 1956:196-197). Although only possessing a moderate education, Yuan had great ability in military affairs and exceptional understanding of political tactics, which rendered him as an influential figure in modern history of China.

In late May 1905, The Russo-Japanese War came to an end. Japan's spectacular victory immediately made this island nation a full-fledged imperialist power. Moreover, it had great demonstrative effect on Asian peoples, especially the Chinese intellectuals and the officials. In the eyes of the Chinese, the defeat of a large autocratic Western power by a tiny oriental constitutional monarchy was proof of the superiority and effectiveness of constitutionalism though in fact Japanese won the war mainly due to their well-prepared military. The leading newspapers in China all agreed that the success of the Japanese and the failure of the Russian was proof of the superiority of constitutionalism. Chung-wai Jih-pao(China and the World Daily) commented that "Russia's weakness would have remained unexposed, and the question of the relative merits of a constitutional monarchy and an autocratic monarchy unanswered, had it not been for this war" ( Chung-wai Jih-pao, May 21 ${ }^{\text {st }}$, 1905; September 20 ${ }^{\text {th }}$, 1905). Wai-chiao Pao (Diplomacy) claimed that "Russia's defeat is the result of her autocracy"(Wai-chiao Pao, November 20"th 1905). In an article entitled “Constitution as the Panacea" Nan-fang Pao (The South) compared ruling a country to piloting a boat:"The destination must be determined before the voyage begins, or the vessel will drift and get nowhere. A constitution is to a state as a compass is to a captain" (Nan-fang Pao, August 23rd, 1905. The above 3 items are cited from Jerome Ch'en, 1972:71;225). The premise that a constitutional monarchy was better than autocracy was now generally accepted among the Chinese officials and intellectuals.

The floundering Chinese were impressed by the fact that nearly all of the flourishing Western powers had constitutional government, while those backward and unimportant nations had not. By this time the people of Russia were also starting a revolution and the Russian government, under the pressure of popular demands, was also showing its intention of adopting a constitution and convoking a duma (assembly) ( Teng, Ssu-yu and Jeremy Ingalls, 1956:198). Under these circumstances, the Chinese were apparently reluctant to leave their country as an autocratic nation. The outcome of the Russo-Japanese War engendered in China an unexpected national clamour for constitutionalism.

As an ardent advocate of constitutional monarchy, Chang Chien seized this opportunity to make his efforts for the introduction of a constitution. Clearly understanding that the Imperial Court would not voluntarily initiate constitutionalism, he decided to resort to the reputation and influence of Yuan Shih-k'ai, the only Han Chinese who could put substantial pressure on the court. Before the peace treaty between Japan and Russia was concluded, Chang Chien wrote in 1904 a letter to Yuan Shih-k'ai advocating a constitutional monarchy, part of his letter reads:

Sir, Now you are commanding the important troops of the empire and shouldering the heavy responsibility of the nation. You should take grave concern for the life or death, the rise or fall of the nation; and you should also realize that the dangers of 1894 and 1900 can not be compared to those of today. It would be futile to change a little bit here and there without having a fundamental reform of the political system, and it would be useless to attempt an appeasement policy while the Russo-Japanese war has not yet been concluded... Victory in the war will be the triumph of constitutionalism over autocracy. What nation today is completely autocratic? Can an autocratic nation survive among all the constitutional nations?...In Japan, Ito, Itagaki, and others worked out a constitution and magnificently achieved the great goal of respect for their emperor and at the same time protection of their people; that is really fortunate for Japan. As far as your ability is concerned, you are not inferior to them. Even I myself think that my ambition and will are also certainly not beneath those of the Japanese constitutionalists (Teng, Ssu-yu and Jeremy Ingalls, 1956:198-199).

It is noteworthy here that Chang Chien said "It would be futile to change a little bit here and there without having a fundamental reform of the political system". In 1901, on his Reasoned Discussion on Reforms, Chang Chien still did not recognize the necessity of fundamental political reform, but now Chang Chien really did.

In June 1905, China's first modern boycott--against the United States' discriminatory treatment of Chinese, and particularly the total exclusion of labours - was taking place mainly in the treaty ports. The anti-American boycott of 
1905 over the Exclusive Act was one of the most conspicuous indications that a new Chinese national spirit had been aroused to a new nationalism which, although it evoked overtones of the tributary system, was in the main a new, anti-imperial drive. The anti-American boycott, which began at Shanghai, soon shifted its centre to Canton. Although it was officially ended late this year, meetings and demonstrations continued into 1907. Numerous incidents accompanying the boycott show that Chinese merchants and workers were prepared to make substantial material sacrifices in order to achieve the broad objectives of the new nationalism (Mary C. Wright, 1968:10). On a short-term basis the boycott could be effective, since to some extent the Chinese merchants were indispensable adjuncts of imperialism. In the long run, however, there was no hope of success. Chinese entrepreneurs were too dependent on foreign capitalists and too much involved in foreign trade to withstand the effects of a decline in imports and exports, the difficulty in getting rid of goods, and a consequence accumulation of stocks (Marie-Claire Bergere,1968:253). What was Chang Chien's attitude toward the anti-American boycott of 1905? On June $27^{\text {th }} 1905$ Yuan submitted a memorial urging the Ch'ing Court to prohibit the growing boycott movement. Learning of Yuan's proposal, Chang Chien immediately sent out a letter advising Yuan to let the people choose their own course, for public opinion should be regarded as the basis of all public policies including foreign policy. After stressing the importance of public opinion, Chang Chien, in the latter half of this letter, again told Yuan that it was the right time to urge the Court to adopt a constitution. In conclusion, Chang wrote in considerate and expectant tone that:

Because you are in a dominant position, you call for the adoption of a constitution will surely be echoed and supported nationally. The establishment of a constitutional monarchy will bring peace and security to both the above and the below. It is a great virtue and an immortal achievement. Sir, don't you have any intention of achieving it? Please do not miss this opportunity. If you do, in the future, you will feel great regret, for somebody else will eventually accomplish this magnificent task some other day (Chang, Hsiao-jo, 1983, Cheng Wen Lu, chuan 3, 9b).

In addition to this letter, Chang Chien had already asked a friend, $\mathrm{Mr}$. $\mathrm{Wu}$, to pass his verbal message to Yuan. In this letter, he simply reiterated and emphasized his opinions about the boycott movement and the constitutional monarchy (Chang, Hsiao-jo, 1983, Cheng Wen Lu, chuan 3, 9a). Apparently Chang Chien liked to make use of nationalistic sentiment immediately after the anti-American boycott of 1905 as a means to push for a constitutional monarchy. This time, Yuan Shih-k'ai did not disappoint him. On July $2^{\text {nd }}$, Yuan, together with Chang Chih-tung and Chou Fu, the governor general of Liang-kiang, memorized the imperial Court and proposed that a constitutional government be set up after due preparation in the following twelve years ( Daniel H. Bays, 1978:127). Probably this joint memorial by the three most powerful governors general exerts great influence upon the Manchu Court.

In the capital, constitutionalism became more popular than ever. High officials like T'ieh-liang, Hsu Shih-ch'ang, Tuan-fang, and Tsai-chen were all in favour the adoption of a constitution. The latter two Manchu officials, particularly, repeatedly gave favourable accounts of constitutional monarchy in the Court (Chang, Hsiao-jo, 1983, Chuan Lu, chuan 7, 13b). In 1906, Chang Chien wrote to T'ieh-liang and reminded him the Westerners were starting to fear the appearance of a constitutional government in China, for they felt the increasing sentiment of nationalism of the Chinese people caused by the large scale boycott and therefore the establishment of a constitutional monarchy must not be delayed. Furthermore, Chang Chien indicated that the Japanese constitution was an appropriate model because of great similarities between the two nations. Since the Japanese had learned much from the constitutions of Germany and England, Chang Chien suggested that their system be consulted in the making of a Chinese constitution. As for the constitutional government of France and the United States, due to the great differences between China and these two countries, it seemed they could offer but small reference ( Chang, Hsiao-jo, 1983, Cheng Wen Lu, chuan 3, 13b-14a), and hence Chang Chien's Japanese style constitutional thought differed from ideas of Liang Ch'i-ch'ao which seemed to be close to British traditional liberalism ( Chang, P'eng-yuan, 1969a, Hsiao, Kung-chuan's Forward, p.2). In fact, as Hsu, Chieh-lin said, the Japanese constitution of 1889 was a constitution of emperor's sovereignty (Hsu Chieh-lin, 1980:169). According to this constitution, the emperor holds absolute power beyond executive, legislative, and judicial authorities. Chang Chien suggested the adoption of Japanese constitution partly because it would be easier for the emperor to accept.

Chang Chien spent much time and energy, through every possible means, to promote the adoption of a constitutional monarchy. In the same letter to T'ieh-liang, Chang Chien also recommended that Manchuria be the first area for the constitutional experiment. He gave no reason for his choice for Manchuria except that it was substantially an administrative affair (Chang, Hsiao-jo, 1983, Cheng Wen Lu, chuan 3,14a). Probably as Liao Sheng-hsiun surmised, "Although Chang Chien was eager to see the realization of constitutional government particularly as it applied to local assemblies in the early stages, he must also have been aware of the Manchu Court's reluctance to usher in the operation of constitutionalism by Han Chinese. The only feasible way to diminish this reluctance was to let the Manchu themselves test the first constitution at their own home. Very probably, this Manchurian experiment would result in success and pave the way for constitutional implementation in the rest of China" (Liao, Sheng-hsiung, 1979:282). Chang Chien's effort, together with Liang Ch'i-chao's massive propaganda and other calls for constitutionalism-such 
as that of Sun Pao-ch'I, the minister to France, made in late March of 1904-eventually drew the aged empire to the brink of a constitutional government.

In the meantime, the reformists under K'ang Yu-wei and Liang Ch'i-ch'ao came into direct contact with the revolutionaries because they were both operating in Japan. When K'ang Yu-wei first arrived in Japan in late 1898, there was an attempt on the part of interested Japanese to promote an alliance between K'ang and Sun Yat-sen. The effort failed as much through disagreements between the two groups on basic issues as through the rise of personal antipathy between the two leaders (Marius B. Jansen, 1954:78-81). Thereafter the reformists and the revolutionaries in Japan fought each other continuously for the allegiance of the overseas Chinese. This group was essential to the reformists and the revolutionaries alike because its members were the chief source of financial support for both. Consequently competition between the two groups was intense. Sometimes this took the form of rough-house tactics, but primary the two factions fought each other by means of Chinese-language newspapers. The central organ of the revolutionaries was the Peoples Tribune (Min Pao), published in Tokyo under the joint editorship of Chang Ping-lin, Hu Han-min, Wang Ching-wei, and Chu Chih-hsin. Opposed to it was the reformists' New People Miscellany (Hsin-min Ts'ung-pao), of Yokahama, edited by Liang Ch'i-ch'ao. Outside of Japan there were opposing newspapers in Hong Kong, Hawaii, San Francisco, Singapore, and Vancouver. The contents of these newspapers reveal quite clearly the stands taken by the two camps. Opposed to the revolutionaries' call for the immediate overthrow of the dynasty and the establishment of a republic, the reformists advocated the establishment of a constitutional monarchy under the Kuang-hsu Emperor. The essays of Liang Ch'i-ch'ao, written in a mixture of classical and vernacular style but with fresh vitality, had a great influence on the mind of the literate Chinese, particularly the younger group. His arguments received a hearing because the ideas embodied in them were fresh and seemed to have a particular pertinence for the contemporary situation (Samuel C.Chu, 1965:62). Facing such pressure both from the home and the abroad, the Empress Dowager was aware that constitutional monarchy should no longer be opposed.

On July $16^{\text {th, }} 1905$, the court issued an edict that appointed Tasi-tse, Tai Hung-tz'u, Hsu Shih-ch'ang, and Tuan-fang to lead a commission to go abroad and investigate foreign political systems in the hope that a certain form of government would be found to best suit the needs of China. On July $27^{\text {th }}$, Shao-ying also named to join the commission. An attempt was made by $\mathrm{Wu}$ Yueh, a revolutionary, to assassinate the five high officials at the railroad station in Peking as they were setting out on their journey abroad. Two of them, Hsu Shih-ch'ang and Shao-ying, were frightened by their narrow escape and withdrew from the mission. Later they were replaced by two other appointees, Shang Ch'i-heng and Li Sheng-to. They were divided into two missions, one visited mainly the United States and Germany; the other, Japan, England, and France. The two groups were abroad from December of 1905 to August of 1906. Prince Ito lectured the visitors to Japan on the necessity of the emperor's retaining supreme power, not letting it fall into the hands of the people (John K. Fairbank, Edwin O. Reischauer, and Albert M. Crag, 1973:736). The dispatch of these five high-ranking officials as special commissions was general viewed as prelude to introduction of a constitution.

The edict of July $16^{\text {th }}, 1905$ was indeed one of the landmarks of Chinese constitutional history. It meant that the Ch'ing Court gave approval to the trend toward constitutional monarchy. What forced the Empress Dowager and her confidants to make this concession were the national clamour for constitutionalism, and the changes of world situations. Nevertheless, without Yuan Shih-k'ai's urging and the persuasion of Tsai-chen, Tieh-liang and Tuan-fang, the Manchu Court might have pretended to know nothing about the constitutionalism for some time and still hesitate to take concrete action to meet the popular demand. Yuan and the above-mentioned advocates undoubtedly played roles in the 1905 constitutional breakthrough. And behind the scene, Chang Chien had subtly pressed Yuan, Tuan-fang and T'ieh-liang to move ahead in their quest for constitutional monarchy. From his own enlightenment and experience, Chang guided influential members of high-level bureaucracy toward constitutionalism (Liao, Sheng-hsiung, 1979:278).

In this promotion, Chang Chien had been both persistent and practical. Now he directed his efforts toward the five commissioners. In December 1905, the commission stop in Shanghai en route from Peking to foreign countries. Chang seized the opportunity, acting as a host, to entertain these distinguished guests with banquets, and at the time persuade them to lend the support to the cause of constitutional government. When the commission had another sojourn in Shanghai on their way home after they completed constitutional investigation in the summer of 1906, Chang Chien again gave them banquets and exhortation. Specifically, he had serious discussions with Tuan-fang and Tai Hung-tz'u. To these two commissioners he stressed that the introduction of a constitution should not be put off any longer, that imperial Court must adopt constitutional monarchy as soon as possible. On behalf of commissioners Tuan-fang and Tai Hung-tzu, Chang drafted a telegram soliciting support from local governors and governors-general throughout the country (Ta, Fu-hui, 1970:31).

In August 1906, all commissioners returned to Peking. Upon their return in the following year two of the commissioners, Tai-Hung-tze(1853-1910) and Tuan-fan(1861-1911), jointly presented to the throne a work on The Essentials of European-American Government. This book is significant in many ways. First, it represents the commissioners' understanding of the principles and operation of constitutional monarchy. Tai, an orthodox of 
Confucian scholar-official, and Tuan-fang, a Manchu official with a reputation for vigour and enlightenment, went as far as the dynasty was willing to go in the matter of constitutional government. Their summary of Western constitutionalism is as interesting for what is rejected as for what is accepted. Secondly, this work underlines the utilitarian interest of the reformers of the period: justification for the constitutional form of government is sought in practical rather than in theoretical terms. In the introductory chapter, for instance, the authors explain that the adoption of a constitution would increase the efficiency of the emperor's rule, not detracted from it. They stress the expectation that when people are allowed to participate in political affairs, their interest in the nation's needs will be stimulated; whereupon a great development of resources will follow, and this in turn will facilitate the government's tax collection. Thirdly, such arguments were not intended for the ear of the Empress Dowager only, they were intended also to provide a reasoned basis on which the throne's actions could be publicized to the entire country. It is noteworthy that the book was published within a year of the commissioners' return. A comparison of the arguments contained in this book with the writings of reformers in contemporary journals shows a close affinity in the points of view. It is clear that this work was part of an effort in traditional government circles to win greater support from the scholars and thereby stem the revolutionary tide (Teng, Ssu-yu and Jeremy Ingalls, 1956:207-208).

The commissioners were received individually in a series of audiences. Separately and jointly, they submitted a number of memorials to the Court and recommended the Japanese model that a constitution and civil liberties including "public discussion" all granted by the emperor so that the emperor could strengthen his position by remaining himself above them all. On August $26^{\text {th }}$, Tsai-feng (the second Prince Ch'un), Prices Ch'ing, Yuan Shih-k'ai, T'ieh-liang, Hsu Shih-ch'ang, Sun Chia-nai, and others to the number of twelve were appointed to form a body to examine and report on the memorials submitted by the returned members of the constitutional commission ( United States Department of States, 1969. 1906:348-349 ). Influenced by Yuan Shih-k'ai, Tsai-feng, the head of the examining body memorized the court on August $29^{\text {th }}$ to express his endorsement of constitutional government. Three days later, the Empress Dowager issued one of the greatest of reform edicts of her reign, the pronouncement of September $1^{\text {st }} 1906$ which proclaimed the Throne's adherence to the principle of constitutionalism and encouraged all generals, officials, the literary classes, and the common people to make due preparation for the coming constitutional government. Part of this significant edict was as follows:

All commissioners' reports are agreed that...the wealth and strength of other countries are due to their practice of constitutional government, in which public questions are determined by consultation with the people. The ruler and his people are as one body animated by one spirit, as a result of which comprehensive consideration is given to the general welfare and the limits of authority are clearly defined... There is nothing which is not made the public concern of the people. Moreover, these nations all learn from one another, and are constantly improving their methods so as to attain the highest degree of prosperity. The success of government and the concord of the people have their origin here. Under these circumstances we can not but consider carefully the form of government best suited to the needs of the times, and adopt a constitutional polity in which the supreme authority shall be vested in the crown, but all the questions of government shall be considered by a popular assembly. These are the foundation principles upon which the perpetuity of the states is to rest. As yet, however, the constitution is not prepared, and the people, too, are not properly equipped with the necessary knowledge...In a few years,...we can, after due consideration of the circumstances, collate and compare the methods of other nations and adopt a satisfactory form of constitutional government as well as fix a date for putting it into operation... Thus we may hope that the people will accumulate the stores of wisdom needed for the establishment of a constitutional form of government ( United States Department of States, 1969. 1906:349-350).

Although "the supreme authority shall be vested in the crown", it is significant that the Ch'ing Court officially admitted "but all questions of government shall be considered by a popular assembly". The edit was a watershed in the development of Chinese constitutionalism. This was the first time in the Chinese history that an emperor officially announced his intention to achieve a constitutional government. In the gestation period, Chang Chien did play a key role behind the scene in the formation of a favourable political climate for constitutionalism and eventually led the Imperial Court to dispatch the investigatory commission in 1905 and to issue the unusual edict of September $1^{\text {st }}, 1906$. There were celebrations and speeches all over the country. Chang Chien felt gratified and respect for Yuan Shih-k'ai's efforts in scoring this victory. In a letter to Yuan, he called Yuan the Okubo Toshimichi of China (Chang, Hsiao-jo, 1983, Cheng Wen Lu, chuan 3, 13a-13b).

Chang Chien's constitutional efforts were matched by the organization of Yu-pei li-hsien kung-hui (The Association to Prepare for the Establishment of Constitutional Government). In the Summer of 1906, as mentioned before, Chang gave banquets for returned commissioners Tuan-fang and Tai-Hung-tz'u in Shanghai. He had already revealed his idea of establishing an organization in order to promote constitutionalism to his two guests (Chang, Hsiao-jo, 1983, Chuan Lu, chuan 7, 14a). Thereafter, along with T'ang Shou-ch'ien and Cheng Hsiao-hsu he led the local gentry to institute a constitutionalists club. The three leaders were all ranking scholars who were influential in their home provinces. T'ang, a holder of Chin-shi degree, was a native of Chekiang. Cheng, a Fukienese, was a Chu-jen of 1882, who had served as an official in Anhwei and Kwangtung prior to his retirement to Shanghai in 1906. On December $16^{\text {th }}$, 1906, the 
Association to Prepare for the Establishment of Constitutional Government was formally founded in Shanghai. Cheng was elected as the president while Chang and T'ang were elected as vice president ( Chang, Hsiao-jo, 1983, Chuan Lu, chuan 7, 14a-14b). Many prominent dignitaries in the three adjoining provinces of Kiangsu, Chekiang and Fukien were attracted to the association, which was very active in the promotion of constitutionalism in the last year of the Ch'ing dynasty. Chang Chien was always a pragmatic constitutionalist. Immediately after the establishment of the association, members voiced many different opinions on the relative speed with which the constitutional movement should be pushed. In this regard, he was willing to let the ultimate initiative come from the government. He urged private individuals to pay their primary attention to industry, education, and self-government which would function as the foundation of constitutional monarchy.

The Ch'ing Court, in late October, 1906, nearly two month after the edict of September $1^{\text {st }}$, ordered the reorganization of the central government as its first step in preparing for a constitutional government. In August, 1907, K'ao-cha Cheng-chih Kuan (The Political Research Institute) was reorganized into Hsien-cheng Pien-ch'a Kuan (The Institute of Constitutional Planning). In September of this year another constitution-study commission was organized and members were sent to the countries with a constitutionalist form of government: Wang Ta-hsieh to England, Yu Shih-mei to Germany and Ta-shou to Japan. At the same time the establishment within a few years of Tzu-cheng Yuan (National Assembly) in Peking and Tzu-I Chu (Provincial Assembly) in various provinces was ordered (Wong king-kong, 1957:44).

\subsection{The Developing Stage of 1907-1911:}

\section{leading to Ch'ing Government's Shortening of 3 Years for Preparation of Constitutional Monarchy}

The constitutionalists were not satisfied with the Ch'ing Court's progress in constitutionalism, and therefore 1907 to 1911, they launched the Petition-for-A-Parliament Movement. The first stage, from autumn 1907 to summer 1908, was devoted to affixing signatures of various provincial constitutionalist bodies to petitions for a Parliament. The second, from October 1909 to November 1910 was active with a high tide of sending petitions for a Parliament. The third, from December 1910 to January 1911 was marked by the Ch'ing rulers suppressing the petitioners' activities (Geng Yunzhi, 1980:116).

In 1907 Liang Ch'i-ch'ao and several of his colleagues founded in Tokyo the Political Information Club (Cheng-wen She) for the express purpose of advocating the establishment of a constitution: (1) responsible parliamentary government; (2) legal reform to insure judiciary independence; (3) local self-government and clear demarcation of authority vis-a-vis the central government; and (4) cautious diplomacy to strive for equal rights in the international community (Immanuel C. Y. Hsu ,1983: 415). Members of this organization who were students in Japan were active in promoting this cause after their return to China. Liang, however, was still persona non grata with the Ch'ing government, which in December, 1907, issued an order prohibiting students from participating in political activities. When members of the Political Information Club persisted in their efforts, a few key leaders were arrested in July, 1908, and the organization in China ordered dissolved (Samuel C. Chu, 1965:65).

The Petition-for-A-Parliament Movement in the year of 1908 was participated in by deputies coming from fifteen provinces carried some 100,000 signatures including about 13,000 signatures from Kiangsu Province. However, the Petition-for-A-Parliament Movement in the year of 1908 was not started by Chang Chien (Geng Yunzhi, 1980: 134).

Although Chang Chien was not so keen on the petition of 1908, he did play a very important role in the second stage of Petition-for-A-Parliament Movement from October 1909 to November 1910. On October 13 ${ }^{\text {th }}$, 1909, Chang Chien, the chairman of the Kiangsu Provincial Assembly approaching Reui-ch'eng, governor-general of Kiangsu Province, trying to enlist his support for the Petition-for-A-Parliament Movement and get him to contact other governor-generals and governors of other provinces to send a joint memorial to the Throne for the establishment of a responsible cabinet (Chang, Chien, 1986, October 13 ${ }^{\text {th }}, 1909$ (H.T.1/8/30) ). Chang Chien also dispatched messengers to make contact with the counterpart Assemblies of other provinces with a view to getting their representatives to come to a conference to be held in Shanghai. As a result, in December, 1909 over fifty representatives from sixteen provinces met at the appointed venue and after sufficient consultation an agreement was reached to send the Capital a petition delegation headed by Sun Hung-I, the chairman of Chili Provincial Assembly, to petition for an earlier convening of a parliament and the establishment of a responsible government. In his Send-off Speech in Honour of the Deputation Bound for the Capital on the Petition Mission on December $24^{\text {th }}, 1909$, Chang Chien encouraged the delegates to appeal unceasingly to the Ch'ing Court in demanding the immediate convening of a Parliament and the establishment of a responsible cabinet:

The foreign threat is more and more serious. But the rulers are pursuing a wrong policy. Therefore the national conditions became more and more critical and people are living in distress. The emergency measure for national salvation is to call a Parliament to organize a responsible cabinet immediately...If our demand is refused, we will try again and again without ceasing...Even we fail ultimately... The future generations will remember that we, the people 
of this age, have done our best ( Chang, Hsiao-jo, 1983, Wen Lu, chuan 10, 10a-11b; Chang, Chien, 1986, December $24^{\text {th }}, 1909$ (H.T.1/11/12)).

In the meantime, Chang Chien wrote a letter to Tsai-feng, the Prince-Regent, persuading him to accept the petition of the Provincial Assemblies. He told the Prince-Regent that (1) the only way to save the nation was to secure support from the people. The best form of cooperation between the government and the people was calling a Parliament. The misery of the melon-cutting of China by the foreign powers would be avoided if they knew the Chinese people in firm support of their government. (2) A responsible cabinet might serve to reduce the responsibility of the throne and the work of Prince-Regent. (3) The situation was so critical that it would be too late to secure the support of the people and to resist foreign aggression after the long nine-year period of preparation for a constitutional government. Everything could be done more effectively after the convening of a Parliament, except the promulgation of the Parliamentary Law and the Election Law. And therefore the Parliamentary Law and the Election Law should be promulgated within six month, a provisional Parliament should be called immediately after that, and the formal Parliament should be convoked in 1911 (Chang, Hsiao-jo, 1983, Cheng Wen Lu, chuan3, 25b-28b).

The petitions, presented on January $26^{\text {th }}$, June $22^{\text {nd }}$, and October $7^{\text {th }}, 1910$, were carefully worked out (Chang, P'eng-yuan ,1968:161; Sheng Pao, October $14^{\text {th }} 1910$ (H.T.2/9/12), page 1, edition 4). According to Chang P'eng-yuan's estimation, 200,000 people signed the first petition, 300,000 the second, and much great numbers (but less than the proposed numbers of 25,000,000) the third (Chang, P'eng-yuan, 1969b:71). Comparing them with 1895 petition, made in a very short time, signified a spontaneous motion of "the younger", "intellectual elites" and the spontaneity created the first shock and the utter rejection of the Tung-Chih Reform tactics. This time, however, the petitioners further requested the government to open a parliament immediately, and a separation-of-three-power political system which had not been requested in 1895 or even in 1898.

The constitutionalists cited three reasons for the immediate convening of a parliament. First, China's international position was very dangerous because the foreign powers had been threatening partition; only a Parliament which showed national unity could prevent the catastrophe of nation's downfall. Second, China was on the brink of bankruptcy, and the outbreak of revolution was imminent; only a Parliament which lent popular support to the government could prevent such disasters. Third, the present government officials had not devoted themselves to their duties; only a Parliament could force them to be responsible (Chang, P'eng-yuan,1968:162-163).

On January $26^{\text {th }}, 1919$, shortly after their arrival in the Capital, the delegates sent in the petition through the Imperial Censor-ate, demanding that a Parliament should be opened within one year. This time the Petition-for-A-Parliament Movement had an all-China scale of representation, but the representation was confined to the members of the Provincial Assemblies. The Ch'ing government refused their demand politely on January $30^{\text {th }}, 1910$ by saying that "Preparations were not yet completed" and that "The people's level of political knowledge was not yet uniform, nor up to the standard of constitutional government" (Geng Yunzhi, 1980:119).

To make up for this failure, which they had half expected, the constitutionalists tried another tack. The delegation organized the All-China Petition-for-A-Parliament Fellow's Society with the head office at Peking, which was to make contact with the constitutionalists in all the provinces and direct them to set up branches in their localities. The new Fellow's Society also made the decision that the Provincial Assembly of Kiangsu, Chili and Kuangtong Provinces should send emissaries to their neighbouring provinces and to foreign countries where there were overseas Chinese to do propaganda among them and win their support (Geng Yunzhi, 1980:120). The second memorial was presented on June $22^{\text {nd }}$ asking the period of constitution preparation be shortened and the date of opening of Parliament hastened. But on $27^{\text {th }}$, the government once again refused to consider this request by saying that:

We have perused the memorial presented through the medium of the Censor-ate by the members of Provisional Assemblies and the representatives of the Banner-men of the various provinces praying for the speedy opening of the Parliament. Let it be understood that in the twelfth moon of the last year when the members of Provisional Assemblies presented a joint memorandum on the same subject, we distinctly decreed that as soon as the nine years' preparation were completed and the qualifications of the general public were up to the required standard, we would without hesitation issue an edict to fix a date for calling a meeting of the Parliament. Every care has been taken by the Throne in the matter in the hope that our subjects would not adopt a superficial form and overlook the substantial result to be achieved...In pursuance of the scheme of their late majesties we hereby adhere to the system of making constitutional preparations for nine years, at the expiration of which period another decree will be issued fixing a date for a meeting of the Parliament. We appreciate perfectly the loyalty of your subjects; but this affair is very important and must be carried out in a methodical manner (United States Department of States, 1969. 1910:337).

Chang Chien was not satisfied with this reply, and thus he contacted the chairmen of other Provincial Assemblies suggesting that a Joint Committee of the Chairmen of All Provincial Assemblies be set up to launch a third petition in Peking in December 1910 during the National Assembly sessions and the chairmen would depart from their respective province in the late November 1910 after the conclusion of their Provincial Assemblies (Kuo-feng Pao, No.23, 
1910:107-108). Finally the chairmen of Provincial Assemblies decided that the meeting in Peking would be arranged earlier to have sufficient time for preparing their petition; and that the title of the delegation to be changed into the Joint Committee of Provincial Assemblies because they were afraid that probably some chairmen could not attend. As a result, in August 1910, the representatives from various Provisional Assemblies met in Peking discussing matters on petition (Chang, P'eng-yuan,1969b:67-68).

Matters remained in an impasse until October, 1910, when the National Assembly, the establishment of which had been promised by the government at the time when it released the constitutional outline, was convened (Samuel.C.Chu, 1965:67). The National Assembly met on October $3^{\text {rd }} 1910$, under the Presidency of Prince Pu Lun, and was opened at noon by the Regent in person. The place of meeting was the converted lecture hall of the Law School in the south-west corner of Tartar city. In the course of his speech the Regent said that, although the opening of the Assembly was only the initial step towards Constitutional Government, it was an emblem of hope of the country's great future ( H. T. Montague Bell and H. G. W. Woodhead, 1969-1974, 1912:371). Thereupon the delegation sent its petition through National Assembly to the emperor. In the meantime, the governor-generals, governors, and generals of as many as 17 provinces also sent a joint memorial to the Throne, appealing for an early convocation of a Parliament with a responsible Cabinet. Finally, on $4^{\text {th }}$ November, 1910, the Manchu Court was forced to issue a decree to promise the shortening of the period of preparation for a constitutional monarchy, with the establishment of a Parliament in 1913 and a responsible cabinet before the convening of the Parliament but simultaneously order that the petitioning organization be disbanded and that no more petitions be presented (Chin Yu-fu, 1934, chuan 28, 1a-2b).

The issuance of the November decree split the constitutionalists into two camps. The one that represented the Association to Prepare for the Establishment of Constitutional Government under the influence of Chang Chien believed that its objective had been reached and that no reasonable purpose could be served by further agitation. For instance, in his diary on November $6^{\text {th }}, 1910$, Chang Chien wrote:

I reached Shanghai and know that the Court issued a decree two days ago promising the establishment of a Parliament in 1913. Hence it is not necessary now to go north to Peking for further agitation (Chang, Chien, 1986, November $6^{\text {th }}$, 1910(H.T.2/10/9)).

And on the next day, November $7^{\text {th }}$, the National Assembly received "congratulatory telegrams" from the Provincial Assemblies of Kiangsu and Chekiang provinces, and from commercial and educational bodies of Kiangsu (Geng Yunzhi, 1980:124).

This view was sharply disputed by representatives of other provinces. Men like T'ang Hua-lung of Hupeh and T'an Yen-k'ai of Hunan persisted in agitating for the immediate opening of Parliament (Samuel C. Chu, 1965:68).

After this November $4^{\text {th }}, 1910$ edict, some constitutionalists in Peking did not simply go home. Instead they drew up further plans in secret before leaving. According to Hsu Fo-su, chief editor of Kuo-Min-Kung-Pao and the liason between Liang Chih-ch'ao and the constitutionalists, the attitude of petitioners changed greatly:

In the third petition, strong words appeared. The summary sentences say: "If the government has no sympathy toward its people's suffering; and will do nothing to prevent revolution or chaos, and is determined not to call a Parliament immediately, we, the representatives, can hardly return home to report to the people that the government was disappointing. We will beg no more". As I understand them, these rather radical words expressed no only the indignation of the representatives, but also indicated that if the government refused them again, they might return to revolution. The Ch'ing Court was very angry after reading the third petition. An edict was send down which ordered the representatives to depart immediately from the capital and return home. The representatives were also angry. The evening after receiving the edict, they all gathered together in my office of Kuo-Min-Kung-Pao and secretly decided: "Let us go back home and report the hopeless political condition of the government to the provisional assemblies. We here decide that we shall lead revolution secretly. All the comrades of the assemblies will form the body of the organization. If there is any event in the future which could lead to an uprising, comrades in each province will respond by proclaiming independence immediately". When the secret decision had been made, they left Peking the next day. The Ch'ing Court, knowing nothing about the decision of the representatives, was delighted to see their peaceful departure. The Court took it for grant that they would be no more disturbances: but the fool's paradise did not last long ( Chang, P'eng-yuan,1968:168-169).

And Wu Hsien-tze, who was a petition representative of the Overseas Chinese in America, recalled the conversation similar terms:

On the day the petition representatives were ordered to leave the capital, they had a secret meeting. They would proclaim provincial independence in demanding a constitution. That T'ang Hua-lung, P'u Tien-chun, and many others who had been petition leaders and had attended the secret meeting seized the opportunity to proclaim their provinces' independence in no trivial incident (Wu Hsien-tzu, 1952:16). 
The constitutionalists of Fentian, Chili and other Provinces, and the students under their influence launched the third stage Petition-for-A-Parliament Movement from December 1910 to January 1911 in demanding further shortening of the preparation period for the convocation of a Parliament. However, in December, 1910 and January 1911, the government cracked down hard on the dissatisfied constitutionalists and students. For instance, the delegates from the Three Northern Provinces were ordered to return to their home provinces under military escort, and one man, Wen Shih-ling of Zhili was sent in exile to Sinkiang (Geng Yunzhi, 1980:124-126).

Why was Chang Chien satisfied with the result? Geng Yunzhi explained that:

The Constitutionalists fell into two categories: those who were led by Zhang Jian (Chang Chien) belonged mainly to Jiangsu and Zhejiang Provinces, representing big capital and high gentry; and those who belonged to other provinces, representing the lesser bourgeois elements. The former had certain relations with the ruling class and tended to compromises. They avoided direct confrontation with the Revolutionists, though they hated them and were prejudiced against them. The Constitutionalists of the latter categories had not so much at stake as the big capital and gentry and less contact with the rulers, their representatives being Sun Hongyi and Wen Shilin of Zhili, Tan Yankai of Hunan, Tang Hualong and Zhang Kuorong of Hubei, Pu Qianjun of Sichuan. Their aspirations for bourgeois constitutionalism were more genuine and they expressed them in actual activities and struggles. They were, as a matter of fact, the backbone of the Petition-for-A-Parliament Movement, organizing and financing it (Geng Yunzhi, 1980:148).

It was true that the constitutionalists split into two groups, and that Chang Chien represented the moderate one. While Sun, Hung-I and others were to readjust their future position, Chang and his comrades from Kiangsu-Cheking area celebrate the concession of the Manchu Court (Chang, P'eng-yuan,1968:180). However, the reason Chang Chien accepted this concession from the Ch'ing government was not mainly due to his class status, but mostly due to his individual characteristics. Because he was a man with "golden means", he was a moderate and practical figure after all, he did not like extremes. And therefore, at this stage, he thought that the government's concession was acceptable. He would like to wait and see the beautiful scenery of the opening of the Parliament three years later in 1913.

\section{Conclusion}

Chang Chien had expressed his feeling that: "the success or failure for the cause of a constitutional monarchy has been one of my greatest concerns in my brief span of life" (Chang Hsiao-jo, 1983, Wen Lu, chuan 10, 8a). His contemporary, Yuan Shih-ka'i had praised Chang Chien as a theoretical leader in promoting constitutional monarchy (Chang Yi-lin, 1966, chuan 7, 6b).

Special characteristics of Chang Chien's constitutional thought are: Constitutional monarchy is based on industry, education and local-self-government and hence industry and political system are mutual related; and a separation-of-three-power constitution under an emperor as content of his constitutional ideas.

Chang Chien's activities on constitutional monarchy: 1904-1906, leading to Ch'ing government's 9-year preparation for constitution monarchy; and 1907-1911, leading to Ch'ing government's shortening of 3 years for preparation of constitution monarchy.

During the petition-for-a-constitution movement in the last years of the Ch'ing period, the constitutionalists backed up their demands with democratic slogans, which the revolutionaries also proclaimed. Both attacked the corruption of the government, though the constitutionalists sought legal rather than violent solutions. Without the constitutionalists opposition, the imperial system might have been preserved and renovated (Chang, P'eng-yuan, 1968:183). The petition-for-a-constitution movement during the last years of the Ch'ing period indeed had unveiled the weakness of the Ch'ing government and paved the way for the revolution of 1911 ( Teng, Ssu-yu, John K. Fairbank and others, 1954: 195).

\section{References}

\section{Chinese References}

Chang, Chien. (1986). Liu-his-ts'ao-t'ang Hih-chi (Chang Chien's Diary). Taipei: Wen Hai Press.

Chang, Hsiao-jo. (1930). Nant'ung Chang Chi-chih Hsien-sheng Chuan-chi (Biography of Mr. Chang Chien of Nant'ung). Shanghai: Chung Hua Bookstore.

Chang, Hsiao-jo. (1983). Chang-chi-tzu Chiu-lu (The Nine Records of Chang Chien). Taipei: Wen Hai Press.

Chang, P'eng-yuan. (1969a). Liang Ch'i-ch'ao yu Ch'ing-chih Ko-ming (Liang Ch'i-ch'ao and the 1911 Revolution), Taipei: Institute of Modern History, Academia Sinica.

Chang, P'eng-yuan. (1969b). Li-hsien Pai yu Hsin-hai Ke-ming (The Constitutionalists and the 1911 Revolution), Taipei: Chinese Academic Writings Commission.

Chang, Yi-lin. (1966). Hsin-t'ai-p'ing-shih Chi (Collection of Works from the Great-harmony-minded Studio of Chang Yi-lin), Taipei: Wen Hai Publisher. 
Chin, Yu-fu. (1934). Hsuan T'ung Cheng-chi (The Political Records under Hsuan T'ung Emperor), Liao Hai Publisher. Hsu, Chieh-lin. (1980). Jih-pen Cheng-chih Lun (On Japanese Politics), Taipei: Lien-ching Publisher.

Ta, Fu-hui. (1970). Chang Chien Tasi Ch'ing-mo Li-hsien Yun-tung Chung te Ti-wei (Chang Chien's Position in the Constitutional Movement of the Late Ching Period), A History of Journal, Vol. 1, pp.27-42.

Wang, Tun-ch'in. (2005). Ch'uan-t'ung yu Ch'ien-chan: Chang Chien Ching-chi Ssu-hsiang Yen-chiu (Tradition and Prospect: A Research on Chang Chien's Economic Thought), Peking: People's Press.

Wang, Tun-Ch'in. (2007). Chang Chien Li-hsien Suu-hsiang chi ch'i Shih-chien Yen-chiu chung-shu (Research Outcome on Chang Chien's Constitutional Thought and Practice), in Wang Tun-Ch'in (2007), Chang Chien Pai-nien Hui-mou (Research Outcome on Chang Chien for the Past one Hundred Years),Nanjing: Nanjing University Press, pp.26-40.

Wu, Hsien-tzu. (1952). Chung-kuo Min-chu Hsien-cheng Tang Tang-shih (A History of Chinese Democratic Constitutionalists Party), Hong Kong.

Yu Li-tzu. (2007). Tong-fang Wu-tuo-pang (Oriental Utopia): Modern Nant'ung, Peking: People's Press.

1-1 Chinese Newspapers

Chung-wai Jih-pao (China and West Daily), May 21 ${ }^{\text {st }}, 1905$; September $20^{\text {th }}, 1905$.

Kuo-feng Pao (National Custom Newspaper), No.23, 1910.

Nan-fang Pao (South Newspaper), August 23rd, 1905.

Sheng Pao (Shanghai Daily News), October $14^{\text {th }} 1910$ (H.T.2/9/12).

Wai-chiao Pao (Diplomacy), November 20 ${ }^{\text {th }}, 1905$.

2. English References

Chang , P'eng-yuan. (1968). The Constitutionalists, in Mary C. Wright (1968), China in Revolution: The First Phase 1900-1913, pp.143-183. New Heaven and London: Yale University Press, 1968.

Daniel H. Bays. (1978). China Enters the Twentieth Century: Chang Chih-tung and the Issues of A New age, 1895-1909, the University of Michigan Press.

Geng, Yunzhi (Keng Yun-chih. (1980). The Movement for A Parliament in the Last Years of the Qing Dynasty, Social Sciences in China, No.3, pp.115-154.

H. T. Montague Bell and H. G. W. Woodhead. The China Year Book, (1969-1974), Nendeln, Liechtenstein : Kraus Reprint, Vol.1(1912).

Immanuel C. Y. Hsu. (1983). The Rise of Modern China, New York and Oxford: Oxford University Press.

Jerome Ch'en. (1972). Yuan Shih-k'ai, California: Stanford University Press.

John K. Fairbank, Edwin O. Reischauer, and Albert M. Crag. (1965). East Asia: The Modern Transformation, Boston: Houghton Mifflin Company.

John K. Fairbank, Edwin O. Reischauer, and Albert M. Crag. (1973). East Asia: Tradition and Transformation, London : Houghton Mifflin Company.

Joseph M. Goedertier. (1968). A Dictionary of Japanese History, New York \& Tokyo : Walker/Weatherhill.

Liao, Sheng-hsiung. (1979). The Elite and Political Development: A Case Study of Chang Chien's Subtle Promotion of Chinese Constitutionalism' Annals, Chinese Association of Political Science, No. 8.

Marius B. Jansen. (1954). The Japan and Sun Yat-sen, Cambridge: Harvard University Press.

Marie-Claire Bergere. (1968). The Role of the Bourgeoisie, in C. Wright (1968), China in Revolution: The first Phase 1900-1913, New Heaven and London: Yale University Press.

Mary C. Wright. (1968). China in Revolution: The first Phase 1900-1913, New Heaven and London: Yale University Press, 1968.

Samuel C. Chu. (1965). Reformer in Modern China: Chang Chien, 1853-1926, NewYork and London: Columbia University Press.

Shao, Qin. (2004). Culturing Modernity: The Nantong Model, 1890-1930, California: Stanford University Press.

Sun, Shun-chih. (1995). The Political Thought of Chang Chien 1853-1926, The Journal of Ming Chuan College, No7, pp.85-148. 
Teng, Ssu-yu and Jeremy Ingalls. (1956). The Political History of China 1840-1928, Toronto: D.Van Nostrand Company .

Teng, Ssu-yu, John K. Fairbank and others. (1954). China's Response to the West, A Documentary Survey 1839-1923, Cambridge: Harvard University Press.

United States Department of States. (1969). Papers Relating to the Foreign Relations of the United States, New York: Washington, D.C. Kraus Reprint Co..

Wong, king-kong. (1957). Chang Chien: A Case Study of Attempts at China's Modernization by the Traditional Gentry. Master Thesis, University of Washington.

\begin{tabular}{|c|}
\hline A Wealthy and Powerful China \\
\hline$\uparrow$ \\
\hline Constitutional Monarchy / A Republic \\
\hline$\uparrow 3^{*}$ \\
\hline Self-government \\
\hline$\uparrow 2^{*}$ \\
\hline Education \\
$\uparrow 1^{*}$ \\
Industry \\
\hline
\end{tabular}

Figure 1. The Main Lines of Chang Chien's Political Thought

\section{Legend:}

$1^{*}$. Industry is the basis of education since educational expenditures have to be supplied by the income of industry. Industry, according to Chang Chien, incorporated agriculture, labour and commerce and it is roughly equivalent to the term of "economic development" of today. Chang Chien saw industry as a means to supply funds for education and also saw industry as a means to save China. He personally devoted himself to the cause of the development of industry and had made great achievements. The success of his economic endeavours enable him to advance education

2*. Education and industry are the foundation of self-government since they are the essentials of self-government. Education, according to Chang Chien, was not merely "instruction", but was the means for the people to obtain wisdom, learning, and knowledge. In order to save China, Chang Chien thought, people should have ordinary knowledge, and ordinary knowledge must be obtained through adequate education. Chang Chien regarded education and industry as the foundation of self-government, and also avenue to a strong nation.

$3^{*}$. Self-government is the basis of constitutional monarchy (or later, a republic) since constitutional monarchy or a republic cannot really be achieved without self-government. Self-government, according to Chang Chien, meant that everyone should devote himself to the development of industry, education, and other local affairs under the leadership of the intellectuals - the representatives of the people, and thus local councils were essential to self-government. Chang Chien saw self-government as the basis of a strong nation. Constitutional monarchy, according to Chang Chien, was a separation of the three-power political system under an emperor. Chang Chien thought that self-government and constitutional monarchy were related and mutually influenced, and thus he was inclined to have a parliament to define the shape and size of taxation.

Chang Chien had played a very important role in the Constitutional Movement: in the gestation period of 1904-1906, he acted behind the scene to push the Ch'ing government to adopt constitutionalism; In the developing stage of 1909-1911, he advocated the Petition-for-a-Parliament Movement and as a result the Ch'ing government shortened the preparation period toward constitutional government by three years or more.

Although for a couple of years Chang Chien had been extraordinarily enthusiastic in the promotion of a constitutional monarchy, he changed from a constitutional monarchist to a republican within less than one month after the 1911 Revolution. Why did he change?

The reasons leading to Chang Chien's change were complicated. However, the underlying reason could be attributed to his political thought with flexibility that industry, education and self-government which were able to be achieved under whether a constitutional monarchy or a republic. The second main reason should be attributed to his pragmatic attitude. He had no choice but to accept the fact that revolution had broken out and that most of the provinces had declared 
independence, and lots of the constitutionalists had changed their attitude toward republican, and he could not reverse the trend. Even his home county of Nant'ung and home province of Kiangsu were under the threats of troops in Nanking. He was concerned with the safety of his own county and province. He thought that the only way to stabilize the society was to accept the republic in order to avoid chaos so as to achieve his industry, education and local self-government program. The third main reason should be attributed to his despair with the Ch'ing government. His Chuan-yuan background made it impossible for him to lead an uprising, but he could accept the fact of revolution. Although he had no ambition in obtaining political power, he had to get involved in politics. Therefore he found a solution by supporting Yuan Shih-k'ai as president of the republic in exchange for the abdication of Ch'ing court under some concession. Behind the scene during the period of North-South negotiation 1911-1912, Chang Chien had played a very important role. 